\title{
Productivity Relevance of Capital Structure Choices
}

\author{
Nasir Uddin ${ }^{1}$ \\ ${ }^{1}$ Department of Business Administration, Yokohama National University, Yokohama, Japan \\ Correspondence: Nasir Uddin, Department of Business Administration, Yokohama National University, \\ Tokiwadai 79-4, Hodogaya-Ku, Yokohama 240-8501, Japan. Tel: 81-45-339-3659. E-mail: \\ uddin-nasir-xc@ynu.jp
}

Received: May 13, 2015

Accepted: August 10, 2015

Online Published: August 25, 2015

doi:10.5539/ijef.v7n9p31

URL: http://dx.doi.org/10.5539/ijef.v7n9p31

\begin{abstract}
This study identified the reasons behind the discrepancies in the result from the past empirical studies about the affect of leverage on the firm value. Most importantly, by using the Malmquist productivity change index and its components as the proxy for corporate performance, the affect of changes in leverage on corporate performance and the affect of corporate performance on changes in leverage are identified. The results reveal that the changes in leverage do not affect the Malmquist productivity change index and its components. The reserve causality tests show that the Malmquist productivity change index and its component do not affect the changes in leverage. Hence it is proved that the changes in leverage do not improve the corporate performance and corporate performance do not affect the leverage.
\end{abstract}

Keywords: malmquist productivity change index, efficiency change, technical change, capital structure, industry performance

\section{Introduction}

What do we know about the affect of financial leverage on firm performance from the empirical work done so far? The empirical studies reported positive, negative, and no relationship (table 2, last column). Consequently, we do not have any unified understanding about the affect of financial leverage on firm performance. This study identified the reasons of the discrepancies in the previous studies and proposes a new design that is used in this study in order to identify the affect of financial leverage on firm performance which can be used in the different industries in the different parts of the world so that by comparing the results; unified understanding can be developed in future.

The broad objective of this research is to check the affect of financial leverage on firm performance. In consistent to the broad objective, the specific objectives are: to identified the reasons behind the discrepancies in previous studies, to measure the efficiency score of the sample firm using a non-parametric technique-data envelopment analysis, to conduct a Malmquist productivity analysis to identify the productivity growth, efficiency change and technical change in the corporate sector, to check the affect of changes in leverage on the firm performance, to check the affect of firm performance on the changes in leverage and to suggest future research directions for the productivity improvements.

In order to achieve the objectives, this study uses data from 14 pharmaceuticals companies listed at Dhaka Stock Exchange Limited-the main stock exchange of Bangladesh for seven years: 2006-2012 and The data is collected from the annual reports of the companies reserved at Bangladesh Securities and Exchange Commission library, Dhaka Stock Exchange Limited library, Chittagong Stock Exchange Limited library and University of Liberal Arts library. The data used in this study is mainly book-value based data.

There is no unique variable to represent the performance of the firm. The variables used in the past literature to represent firm performance are return on equity, return on sales, return per employee, return on total assets, EPS and operating cash flow to total assets. These measures represent partial productivity, hence should not be candidate for the corporate performance. However, this research has used a newer measure called Malmquist productivity chage index and its components as the measure of corporate performance. The Malmquist productivity change index and its components are estimated based on multiple inputs and outputs. Specifically, in this study, productivity change index is determined by using total fixed assets, and wages \& salary as input variables and net profit, and value added as output variables. A number of sensitivity analyses are conducted by 
using different set of inputs and outputs but the results are found unchanged.

Two types of the variables are used in this study to check the dependences: dependent variable and independent variables. In the performance model, the dependent variable is the industry productivity change index and in the leverage model, the dependent variable is the changes in leverage. The affect of changes in leverage on the Malmquist productivity \& its components and the affect of the Malmquist productivity \& its components on the changes in leverage are checked by using ordinary least squares (OLS) regressions. The control variables are selected from the variables used in determining the determinants of capital structure by Uddin (2015a).

Data envelopment analysis (DEA)-like linear programming problem developed by Färe et al. (1994) is used to estimate the efficiency of the firms. As there is no single indicator of firm performance, the efficiency scores is used to form the Malmquist productivity change index and its components which are used as proxy for the industry performance. The OLS regressions are used to check the affect of the changes in financial leverage on firm performance and the affect of the firm performance on the changes in finance leverage. In the both of the tests, a set of firm characteristics are used as control variables.

This study claims four academic contributions: firstly, this study formed two new models to test the affect of the changes in leverage on the changes in firm performance and the affect of changes in performance on the changes in leverage. Secondly, this study used the Malmquist productivity change index and its components as the proxy for the corporate performance and tested the two competing hypothesis: efficiency risk hypothesis and franchise value hypothesis. Thirdly, the study provides new evidence from the comprehensive and total data of a corporate sector listed at Dhaka Stock Exchange Ltd. Finally, the design used in this study should be used on data from various economy of the world in order to develop unified understanding on the affect of financial leverage on firm performance.

The rest of the study is organized as under: second section is about capital structure and firm performance: affects of leverage on firm performance and affects of firm performance on leverage, third section discusses the reasons for the discrepancies in the previous studies, fourth section is about the models of the study, Fifth section deals with the results of the study, and final section is about conclusion and future direction based on the study.

\section{Capital Structure and Firm Performance}

\subsection{Affects of Leverage on Firm Performance}

The basis of the famous agency cost theory (Jensen \& Meckling, 1976) is the difference between the objectives of the managers and the objectives of the shareholders. In details, the shareholders want to maximize the value of the firms but the managers want to maximize their consumptions and benefits. As a result, their objectives are not aligned. To solve the problem, Jensen (1986) argued to use debt as an alignment tool to mitigate the agency costs from the conflict of the shareholders and the managers. Jensen argued that using debt will reduce excess cash. Besides, manager will be under pressure to generate sufficient cash to pay fixed interest payments and instalments of loan or the principal and the interest at a time (Grossman \& Hart, 1982). Thus use of debt decreases the possibility of misuse of the fund and perquisites consumption of the managers. Hence, all else equal, leverage affects firm performance positively.

However, if debt is used as capital, conflict between the equity holders and the debt holders can generate underinvestment problem or debt overhang problem when there is a default risk (Myers, 1977). In consistent with Myers, Jensen (1986), and Stulz (1990) showed that debt prevents overinvestment problem however creates underinvestment problem. To minimize these costs, debt should not be used in the capital structure. Hence, all else equal, the affect of leverage on firm performance is negative. Thus the affects of leverage on firm performance may be positive or negative or zero.

\subsection{Affects of Firm Performance on Leverage}

The reverse causality-efficiency may affects financial leverage. The affects of firm performance on leverage are described by two competing hypothesis: efficient-risk hypothesis and franchise-value hypothesis. Berger and Bonaccorsi di Patti (2006) argued that efficient firms are profitable firms. The profits are as defence against portfolio risk in substituting equity for debt. In addition, it is assumed that efficient firms could minimize the total agency cost and financial distressed/bankruptcy cost substantially. Consequently, as per efficient-risk hypothesis, efficient firms can use more debt. In a sense, efficient-risk hypothesis is a version of the trade-off theory where differences in efficiency enforce the process of reaching at optimal capital structure. Hence, all else equal, efficiency affects leverage positively. This affect is termed by substitution effect.

However, efficient firms are profitable firms and efficient firms may be interested in not to use debt in order to protect economic rent generated from the thread of liquidation for the shareholders (Demsetz, 1973; Berger \& 
Bonaccorsi di Patti 2006). So, in addition to substitution effect, there is an income effect. As a result, as per franchise-value hypothesis, efficient firms use less debt. Hence, all else equal, efficiency affects leverage negatively. Thus efficient-risk hypothesis and franchise-value hypothesis predicts efficiency and leverage relationship in opposite direction. Although it is not possible to identify substitution and income effect separately, our specification can determine which effect dominates the other.

\section{Reasons for the Discrepancies in the Results of the Previous Studies}

Empirical studies are conducted to determine the affects of leverage on firm performance produced different results (table 2, last column). At the same time, a researcher, after conducting a research, tried to compare the results with the results of the others' studies without minimum base for such comparison. For example, Ofori-Dankwa and Julian (2013) compared their results with Simerly and Li (2000). Their comparison is not correct as their studies are not conducted by using the same variables. By a careful examination, the reasons of the discrepancies in the previous studies are identified and reported in this section. The reasons for the discrepancies are corporate environment, leverage measure, data analysis technique, uncommon control variables, performance measure, data issue, market type-bank or market-based economy, and market location (table 2).

\subsection{Measuring Performance}

Empirical researchers used four types of variables to measure the firm performance: accounting-based measures, productivity-based measures, market-based measure and non-parametric DEA efficiency score. Firstly, the accounting-based measures are return on equity, return on sales, return per employee, return on total assets, EPS and operating cash flow to total assets. The measures reflect short-term profitability of the firm and fine as the measures of short-term performance of the firm. However, there are several problems of using these measures of performance. The measures do not represent long-term performance and long-term return of the firm. Besides, the measures do not consider all of the agency costs. Moreover, the measures are manipulated by insiders and affected by the accounting practice. Last but not least; the measures should not be used when data is collect from developing country where ethical standard is not high.

Secondly, the productivity-based measures used/suggested to measure performance of the firms are profitability per employee and total factor productivity. The profitability per employee is different for capital-intensive and labour-intensive industries. In addition, productivity is an end result of multiple inputs, and should not be calculated based one input factor. Hence, the productivity per employee is not a good measure of corporate performance. Total factor productivity or technical productivity is a part of the total productivity, which is because of capital input or labour input and is estimated by using Cobb-Douglas production function, is a measure of firm performance. The measure represents the true long-term growth and forward looking performance of the firm (Hu \& Izumida, 2008).

Thirdly, the market-based measure is Tobin's Q-the market value of the assets divided by the replacement costs of the assets. This measure is the indicator of the long-term performance of the firm that shows the long-term growth and forward looking performance of the company. The indicator is widely used as a measure of corporate performance. However, Demset and Villalonga (2001) argued that since the numerator of Tobin's Q is partially due to the intangible assets but the denominator is the replacement cost of the fixed assets, hence, this is not a good measure of corporate performance. In addition, the depreciated book value of the assets is used as the replacement cost of the assets.

Finally, the Efficiency score generated by the non-parametric technique called data envelopment analysis (DEA) is used to measure the corporate performance too. This measure can consider multiple inputs and multiple outputs. The technique DEA has several advantages over regression analysis. Unlike regression analysis, there are no functional form, no dependent $\&$ independent variables, no matter of parameter estimates and no error term. In addition, in regression analysis, inefficient branches are compared with the respective average of the branches/ respective branches on the regression line. However, in DEA, inefficient branches are compared with best practice branches. Thus different methods of measuring corporate performance have produced different results.

\subsection{Measuring Capital Structure (Uddin, 2015a)}

In order to determine the determinants of capital structure, it is important to define capital structure or financial leverage. The capital structure is the combination of debt and equity (Van Horne, 2002). But the word "Capital Structure" has different meaning to different authors. Leverage measure can be defined in terms of convertible bond, short-term debt, long term debt, and total debt. In addition, Measures of leverage can be defined on the 
basis of inclusion of total liabilities, total assets, net assets, interest expense, EBIT, and EBITDA. Similarly, leverage can be measured in terms of market valued and book value. Thus, it is noticeable that leverage for the same firm can be different based on the variables used to calculate the financial leverage. Which measure should be used is depending on the objective of the measurement.

In defining leverage and determining the determinants of leverage-book value based leverage should be used for several reasons. Myers (1977) argued for book value as it represents assets in hand and not affected by growth opportunities. In addition, book value does not fluctuate and realistic as corporate finance policy guide. Market value comes from share market. But capital structure is not rebalanced after changes in stock price for the rearrangement costs. However, market value based leverage should be used for convincing following reasons. Market value is consistent with wealth maximization goal of the corporate organization. In addition, market value is also managerially relevant (Welch, 2004). Moreover, book value can be negative but asset cannot be negative. Finally, book value is plug number, and book value is backward looking, but, market value is forward looking. As a result, Barclay, Morellec, and Smith (2006) argued that there is no reason to match the two value.

In consistent with the above discussion, Harris and Raviv (1991) summarize the matters as 'the interpretation of the results must be tempered by an awareness of the difficulties involved in measuring both leverage and the explanatory variables of interest. In measuring leverage, one can include or exclude accounts payable, accounts receivable, cash and other short-term debt. Some studies measure leverage as a ratio of book value of debt to book value of equity, others as book value of debt to market value of equity, still others as debt to market value of equity plus book value of debt. In addition to measurement problems, there are the usual problems with interpreting statistical results.' The possible measures of financial leverage are discussed in following.

\subsubsection{Total Liabilities/Total Assets}

This is the broadest measure of financial leverage and could be a measure of what is left for the equity holders at the time of liquidation. However this measure does not tell about the level of risk of bankruptcy in the near future. This measure has some other problems. For example, total liabilities include some liabilities which are not related with financing but are used for transaction purpose. In the same way, pension liabilities arising from labour contact markets influence this ratio. Hence liabilities like accounts pay able, pension liabilities overstate this ratio.

\subsubsection{Total Debt/Total Assets}

A better measure for financial leverage is total debt to total assets. The liabilities like untaxed reserve and accounts payable do not affect this ratio. As the non-debt liabilities offset some assets which are not considered in this ratio, this ratio as measure of financial leverage is problematic. For example, trade credit level influence this ratio substantially. So, this measure cannot be a true measure of financial leverage. All of the researchers used this ratio as a measure of financial leverage.

\subsubsection{Total Debt/Total Net Assets}

A corrected measure of the above ratio is total debt to total net assets ratio. This ratio is calculated after the adjustment of total assets for non-debt liabilities. This ratio is not affected by trade credit. Total net assets are equal to total assets minus accounts payable minus other liabilities. The ratio is still influenced by assets held against pension liabilities.

\subsubsection{Long-Term Debt/Total Assets}

Short term debts are used for mainly transaction purpose while long-term debts are used for financing purpose. So, the ratio to measure financial leverage should be long-term debt to total assets. All of the researchers used this ratio as a measure of financial leverage.

\subsubsection{Short-Term Debt/Total Assets}

Titman and Wessels (1988) and Myers (1977) argued that growing firms should use short-term debts. Flannery (1986) argued that firm borrows short-term, if there is a possibility of improvement in the credit rating of the firm in future. Bevan and Danbolt (2000) finds significant difference in the determinants of corporate capital structure between short-term and long term debt. They also argued that firm chooses short-term as short-term is cheaper than long-term debts. Besides, the author of this paper has observed that many companies in the developing country do not have any long term debt. Graham and Harvey (2001) finds that, in general, credit rating is important in debt decision making but not used in making decision between short-term vs long-term.

\subsubsection{Convertible Debt/Total Assets}

By issuing convertible debts, firm pays low as coupon rate and lender can convert the debt to equity or cash in 
future at maturity date. Pecking order theory argues that, because of information asymmetry and transportation cost, companies should use internal fund for financing first, debt second, then convertible debt and equity last. The firms having low credit rating and high growth use convertible debt. Jensen and Meckling (1976), Smith and Warner (1979), and Green (1984) argued that the agency costs of growth opportunities could be minimized if the projects would be financed by convertible debts. Because of the implication of convertible debt financing, in this study capital structure is considered in convertible debt also. The ratio to measure capital structure is convertible debt to total assets.

\subsubsection{Debt/(Debt +Equity)}

Weston and Brigham (1984) have defined the capital structure as "Capital Structure is the permanent financing of the firm, represented primarily by long-term debt, preferred stock and common equity, but excluding all short-term credit. Thus, a firm's capital structure is only a part of its financial structure. Common equity includes common stock, capital surplus, and accumulated retained earnings." Agency theory developed by Jensen and Meckling (1976), Myers (1977) are concerned and based on agency cost of debt, and agency cost of equity. Consequently, a debt to equity ratio is more relevant. But if a company uses zero equity, then the debt to equity ratio becomes infinity. So the modified equivalent ratio is debt to debt plus equity ratio. Ross et al. (2012) used this ratio to explain the relationship between agency cost and increase in debt. In addition, Rajan and Zingales (1995) described the ratio as best for representing past financing behaviour.

The above each ratio should be two based on whether book value or market valued is used in the denominator.

\subsubsection{EBIT/I}

Aghion and Bolton (1992) considered capital structure in terms of control of ownership and hence the capacity of payment of the interest payment is very important. As a result, a measure of interest coverage is more relevant as a capital structure ratio. The interest coverage ratio is EBIT/I. This ratio is all right if an investment equivalent to depreciation is needed to keep the business on going. The ratio is calculated based on the assumption that short-term liabilities and short-term debt will be renewed. In addition, this ratio is very responsive to income oscillation.

\subsubsection{EBITDA/I}

If investment equivalent to depreciation is not required for keeping the business on going than appropriate interest coverage ratio is earning before interest, taxes and depreciation (EBITDA) divided by interest (I). This ratio is also based on the assumption that short-term liabilities and short-term debts will be renewed. This ratio is also very sensitive to earning variation.

At the time of conducting research in corporate capital structure, the researchers should keep the above measures of financial leverage in their minds. Table-1 summarizes measures of capital structure and their definitions.

Table 1. Constructs, indicators of the leverage and definitions of the leverage

\begin{tabular}{lll}
\hline Constructs & Indicators of leverage & Definitions of leverage \\
\hline Capital Structure & TL/TA & Total Liabilities/Total Assets \\
TD/TA & Total Debt/Total Assets \\
TD/TNA* & Total Debt/Total Net Assets \\
LTD/TA & Long Term Debt/Total Assets \\
STD/TA & Short Term Debt/Total Assets \\
CD/TA* & Convertible Debt/Total Assets \\
D/(D/E) & Debt/(Debt + Equity) \\
EBIT/I & Earnings Before Interest and Tax to Total Interest Paid \\
EBITD/I & EBIT \& Depreciation to Interest Paid \\
\hline
\end{tabular}

Source: Literature Review, *measures not used in this study.

\subsection{Environmental Dynamism (Uddin, 2015a)}

By using the U.S. data for 700 firms form 46 sectors, Simerly and Li (2000) showed that environmental dynamism is a very important variable in determining the relationship between capital structure and firm performance. They showed that firms having high environmental dynamism should use low level of debt for better performance. On the other hand, firms having low environmental dynamism should use more debts for 
better performance. They concluded that the relationship between financial leverage and firm performance may be positive, negative or insignificant based on environmental dynamism. However, the findings of Ofori-Dankwa and Julian (2013) are opposite of Simerly and Li. By using the data for 55 firs from Ghana they showed that high environmental dynamism firms should use more debt and low environment dynamism firm should use less debt. They argued that institutional differences are the reasons behind the environmental paradox.

\subsection{Data Analysis Technique}

\subsubsection{Single Equation vs. Simultaneous Equation}

The various techniques and model specifications used in the study generated different results. In most of the cases, ordinary least square is used to estimate the parameters by assuming that capital structure is exogenously determined. However, when capital structure is endogenously determined, single equation model can generate biased results. In that case, simultaneous equation and instrumental variables regression will generate better estimates. The general form of the simultaneous equations should be as follows:

\section{leverage $=f$ (performance, controls) \\ performance $=f$ (leverage, controls)}

In addition, there may be no systematic affect of financial leverage on the firm performance. However, a statistically significant result may be found because of unobservable heterogeneity among sectors in the study. In that case, fixed effect method and controlling for specific effects will generate better estimates.

\subsubsection{Data Envelopment Analysis vs. Regression Analysis}

All though many of the empirical papers used regression to examine the empirical affect of leverage on the firm performance, recently a few papers have used data envelopment analysis. The level of productivity is determined by regression analysis and data envelopment analysis is different. The reasons behind these discrepancies are: Unlike regression analysis, DEA compute productivity score based on multiple inputs and multiple outputs variables whereas regression can consider one dependent variable. Moreover, in the data envelopment analysis, inefficient branches are compared with the best practice branches to compute the productivity scores; in the regression analysis, the inefficient branches are compared with the averages of the branches. Figure-1 presents a hypothetical illustration of productivity analysis by using data envelopment analysis and regression analysis.

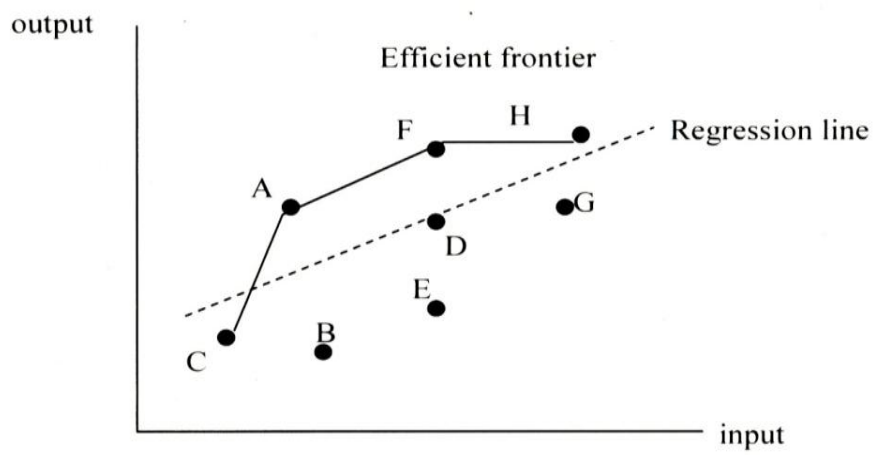

Figure 1. DEA versus regression (Hypothetical illustration)

Source: Lin, Liu, and Chu (2005)

\subsection{Uncommon Control Variables}

In addition to the variables of leverage and firm performance, different authors used different control variables which can be a cause of producing different results in the analyses. Frank and Goyal (2009) showed that an inclusion of an insignificant variable in the regression equation make a significant variable insignificant. In order to compare the results of the two studies, all of the variables should be the same.

\subsection{Data Issues}

The data quality, sample/data selection process, objective of the study, source of data, mistakes and biased-ness can be the sources of the discrepancies. For instance, data collected for two sources may produce inconsistent result. In addition, all most all studies collected data from listed companies which are larger than non-listed 
companies. Furthermore, the data is used from developed country and developing country can produce different results. Because the data collected from different regions-developed and developing may represent the differences in institutional characteristics, legal aspects, regulatory, institutional differences, culture, disclosure levels, and shareholder protection and many other factors.

\subsection{Types of Market: Bank-Based/Market-Based}

Data collected on the samples from bank-based economy (Anglo-America) and market-based (Japanese-European) generated different results as there are significant different developments in the financial and legal systems of the two national systems of the corporate governance. For instance, block holders and corporate performance are positively related in Continental Europe and East Asian economies whereas the relationships in the market-oriented countries like UK and USA are insignificant.

The reasons for the discrepancies in the results of the previous studies are summarized in the Table 2.

Table 2. Summaries at empirical research on the relationship between capital structure and corporate performance

\begin{tabular}{|c|c|c|c|c|c|c|}
\hline Author & Sample and Period & Data Source & Performance & Leverage & Methodology & Summary at Findings \\
\hline $\begin{array}{l}\text { Simerly and Li } \\
\qquad(2000)\end{array}$ & $\begin{array}{c}700 \text { firms, } 46 \text { sectors } \\
1988-1992\end{array}$ & $\begin{array}{c}\text { US Industrial Outlook 94, } \\
\text { Compustat, Stern Steward } \\
\text { Market Performan -1000 report }\end{array}$ & ROA, ROI & $\begin{array}{l}\text { Long-term } \\
\text { debt/equity }\end{array}$ & OLS & $\begin{array}{l}\text { Capital structure may be positively or } \\
\text { negatively related based on industrial } \\
\text { dynamism. high dynamism-low debt, low } \\
\text { dynamism-high debt }\end{array}$ \\
\hline $\begin{array}{c}\text { Berger and } \\
\text { Bonaccorsi di Patti } \\
\text { (2006) }\end{array}$ & $\begin{array}{c}\text { US banking industry, } \\
1990-1995\end{array}$ & $\begin{array}{l}\text { Reports at income and } \\
\text { condition (call reports) }\end{array}$ & Efficiency score & $\begin{array}{l}\text { Equity to } \\
\text { assets }\end{array}$ & $\begin{array}{c}\text { DEA and Simultaneous } \\
\text { equation }\end{array}$ & $\begin{array}{l}\text { Leverage effects performance positively. No } \\
\text { evidence at reserve causality. }\end{array}$ \\
\hline Ebaid (2009) & $\begin{array}{l}\text { non-financial Egyptian } \\
\text { listed firms, 1997-2005 }\end{array}$ & Published annual reports & $\begin{array}{l}\text { ROA, ROE, Gross } \\
\text { pratit margin }\end{array}$ & & $\begin{array}{l}\text { Multiple regression } \\
\text { analysis }\end{array}$ & weak-to-no impact \\
\hline $\begin{array}{l}\text { Margaritis and } \\
\text { Psillaki (2010) }\end{array}$ & $\begin{array}{l}3 \text { French sectors: } \\
\text { Chemical, Textile and } \\
\text { Computers, 2002-2005, }\end{array}$ & Diane data base & Efficiency score & Debt/Assets & $\begin{array}{l}\text { DEA and Quartile } \\
\text { regression }\end{array}$ & $\begin{array}{l}\text { Positive relationship for whole data set, } \\
\text { efficiency effect leverage positively. }\end{array}$ \\
\hline Gosh (2012) & $\begin{array}{c}1022 \text { NYSE, } 244 \text { AMEX } \\
\text { firms, 1772 NASDAQ } \\
\text { firms, 1985, 1989, 1994, } \\
1999,2003\end{array}$ & Compustat & $\begin{array}{l}\text { ROA, ROE, } \\
\text { OCF/Assets }\end{array}$ & $\begin{array}{l}\mathrm{D} / \text { Assets } \\
\mathrm{D} /(\mathrm{D}+\mathrm{E})\end{array}$ & OLS & $\begin{array}{l}\text { Negative relationship between capital structure } \\
\text { and performance at NYSE firms. } \\
\text { no relationship is found between the two } \\
\text { variables for NASDAQ firms, AMEX firms }\end{array}$ \\
\hline $\begin{array}{l}\text { Ofori-Dankwa and } \\
\text { Julian (2013) }\end{array}$ & $\begin{array}{c}55 \text { Ghanaian firms, } \\
\text { 1996-1999 }\end{array}$ & Ghana Club 100 & $\begin{array}{l}\text { ROS, } \\
\text { practicability per } \\
\text { employ }\end{array}$ & Equity/sales & OLS & $\begin{array}{l}\text { Findings at empirical study in developed } \\
\text { country may not fully apply in emerging } \\
\text { economics. } \\
\text { Sometimes may work in opposite direction. } \\
\text { stable-equity financing, dynamic debt financing }\end{array}$ \\
\hline
\end{tabular}

Source: Literature Survey.

\section{The Models of the Study}

\subsection{The Malmquist Productivity Change Index and Its Components Models (Uddin, 2015b)}

\subsubsection{Specification of the Model}

Determining input and output variables in order to estimate the productivity of the sample firms are one of the biggest challenges of this study because of very limited empirical research in this field. However, Margaritis and Psillaki (2010) used two inputs: labour and capital as input variables and value added as output variables, where the input variables- labour is measured by total labour and capital is measured by fixed assets. The output variables-value added is defined as net profit plus depreciation and labour cost: wages plus salaries plus benefits. The first part (net profit plus depreciation) is the return to capital (capital, land, and assets) and second component (wages plus salaries plus benefits) is the return to labour. In addition, Berger and Bonaccorsi (2006) used total equity to total assets and return on equity as inputs and output variables respectively. Lin, Liu, and Chu (2005) used assets and equity as inputs variables and operating revenue and net income as output variables in order to assess efficiency of the Taiwan's shipping industry.

Data envelopment analysis is a data sensitive technique. Using more number of inputs and outputs variables make the DMUs unique and less possibility of being compared with the more numbers of best practice branches. As a result, as the number of inputs and outputs variables increases, the possibility of being efficient increases and vice-versa. In addition, sample size variables should be substantially more than number of outputs times number of inputs. Mostafa (2007) indicated that sample size should be more than three times of bigger between number of inputs and number of outputs. 
In order to select the inputs and outputs variables for this study, this study considered all of the input and output variables available from the literature survey (Table 3). From the literature survey, seven variables are available as input variables and four variables as output variables. A correlation coefficient analysis is conducted in order to check the multi-colinearity and reduce the number of the variables.

Table 3. Inputs and outputs variables

\begin{tabular}{llll}
\hline & List of inputs variables & & List of outputs variables \\
\hline - & Salary and wages (= labour) & - & Value added (= EBIT + dep. + wages \& salary) \\
- Fixed assets (= capital) & - & Return on equity \\
- Total assets & - Operating revenue (= sales) \\
- Total equity to total assets & - & Net income (= net profit) \\
- Equity & & \\
- Debts & & \\
- Total expenses & \\
\hline
\end{tabular}

Source: Literature Survey.

Table 4 shows the correlation coefficients of the all possible pairs of the input and output variables. The coefficients show that total fixed assets are strongly correlated with total debt (0.84), total equity (0.96), and total assets (0.97). Among these four variables, total fixed assets is selected as one of the input variables. The variables: wages \& salary and total expenses are strongly positively correlated (0.90). Between these two variables, wages and salary is accepted as the second input variable. Finally, for the analysis sample, total fixed assets, and wages and salary are selected as input variables. In the case of output variables, sales or revenue and net profit is strongly positively correlated (0.94). From these two variables, net profit is selected as an output variable. And the second output variable is value added. Thus the input variables are total fixed assets and wages and salary and the output variables are net profit and value added.

Table 4. Correlation matrix for the input and output variables

\begin{tabular}{|c|c|c|c|c|c|c|c|c|c|c|c|}
\hline & $T D$ & $T E$ & $T A$ & $T F A$ & $T E / T A$ & $W \& S$ & Texp & $S=R$ & $N P$ & $V A$ & $R O E$ \\
\hline Total Debt & 1.00 & & & & & & & & & & \\
\hline Total Equity & 0.82 & 1.00 & & & & & & & & & \\
\hline Total Asset & 0.91 & 0.96 & 1.00 & & & & & & & & \\
\hline Total Fixed Asset & 0.84 & 0.96 & 0.97 & 1.00 & & & & & & & \\
\hline TE/TA & 0.22 & 0.44 & 0.35 & 0.36 & 1.00 & & & & & & \\
\hline Wages and salary & 0.80 & 0.79 & 0.83 & 0.76 & 0.28 & 1.00 & & & & & \\
\hline Total Expenses & 0.78 & 0.76 & 0.82 & 0.75 & 0.29 & 0.90 & 1.00 & & & & \\
\hline Sales $=$ Revenue & 0.80 & 0.81 & 0.86 & 0.78 & 0.29 & 0.88 & 0.93 & 1.00 & & & \\
\hline Net Profit & 0.71 & 0.83 & 0.84 & 0.81 & 0.33 & 0.80 & 0.86 & 0.94 & 1.00 & & \\
\hline Value Added & 0.40 & 0.56 & 0.54 & 0.55 & 0.23 & 0.51 & 0.57 & 0.63 & 0.67 & 1.00 & \\
\hline$R O E$ & -0.18 & -0.23 & -0.20 & -0.21 & -0.48 & -0.09 & -0.08 & -0.07 & -0.08 & -0.06 & 1.00 \\
\hline
\end{tabular}

Source: Author's calculations.

The ratio variables do not follow convex to the origin characteristics, hence: total equity to total assets is not considered as input variable and for the same reasons return on equity is not considered as output variable in this study. In addition, a sensitivity analysis is conducted by using an alternative combination of variables-total assets and total expenses as input variables and sales or revenue and value added as output variables. The sensitivity analysis has produced the similar results to the main analyses.

At the time of the analyses, it is assumed that for an input variable "less is better" and for an output variable "more is better". The Figure 2 presents that industries in the study uses fixed assets and salary \& wages as the input variables and produces net income and value added as the output variables. 


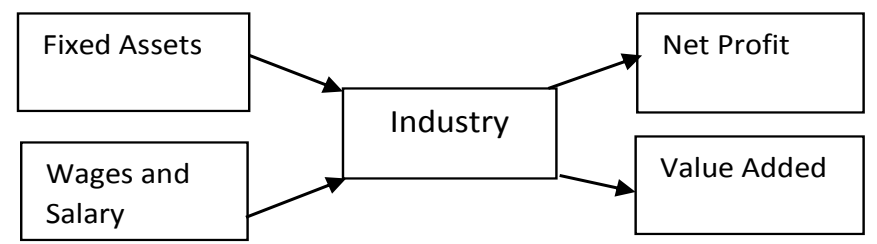

Figure 2. Firm input and outputs

\subsubsection{Output Distance Function}

The Malmquist Productivity Index can be constructed by one of the two ways: by using the ratios or by using the distance functions. Mlima (1999) constructed the Malmquist productivity index as a ratio of the Malmquist output-quantity index to the Malmquist input-quantity index. As an alternative, the Malmquist productivity index can be constructed by using the distance functions. The use of the distance functions enables consideration of multiple inputs and multiple outputs. In addition, there is no need of the profit maximization or cost minimization assumption when the Malmquist productivity index is constructed by using the distance functions. This study determines the Malmquist productivity index by using the distance functions.

Malmquist productivity index are divided into two: Malmquist input-productivity index and Malmquist output-productivity index. The Malmquist input productivity index is constructed based on the input distance functions and the Malmquist output productivity index is constructed based on the output distance functions. An input distance function describes possible maximum decrease in inputs for a given outputs and an output distance function describes possible maximum increase in outputs for a given inputs level. The value of a distance function is varying between 0 and 1 . In this study, Malmquist output productivity index is constructed.

In order to define the distance function, consider, a sample of $\mathrm{n}$ DMUs and a production technology that by using $x^{t}$ input producing $y^{t}$ output in the time period $\mathrm{t}=1 \ldots \mathrm{T}$. For considering multiple inputs and outputs, the inputs and the outputs vectors are considered by using inputs, $x^{t}\left(x_{1}^{t},---, x_{n}^{t}\right)$ the firms produces outputs, $y^{t}\left(y_{1}^{t},-, y_{m}^{t}\right)$ in the time period $\mathrm{t}=1 \ldots \mathrm{T}$. Assume, $\mathrm{P}^{\mathrm{t}}$ is the output set. Now, in the set builder form, the output set is:

$$
\mathrm{P}^{\mathrm{t}}(\mathrm{x})=\left\{y^{t} / x^{t}: x^{t} \text { can produce } y^{t} \text { at time } \mathrm{t}\right\} \text { where, } \mathrm{t}=1 \ldots \mathrm{T}
$$

Shepherd (1970) distance function that is used for the Malmquist output productivity index is as follows:

$$
D^{t}(y, x)=\min \left\{\delta \in(0,1]:(y / \delta) \in P^{t}(x)\right\} \quad \mathrm{t}=1 \ldots \mathrm{T}
$$

The value of the distance function is less than or equal of one i.e., $0 \leq \mathrm{D}(\mathrm{y} \mathrm{x}) \leq 1$ when $\mathrm{y}$ is in the output possibility set, i.e. $y \in P(x)$. The value of the distance function is equal to one, i.e. $\mathrm{D}(\mathrm{y} \mathrm{x})=1$ when $\mathrm{y}$ is on the frontier line and the value of the distance function is less than one, i.e. $\mathrm{D}(\mathrm{y} \mathrm{x})<1$ when y belongs in the other area of production possibility set except on the frontier line. If the value of the distance function is one, the DMUs efficient and otherwise not efficient.

The following Figure 3 is a pictorial presentation of the output possibility set and the distance functions for the firm using one input and producing two outputs.

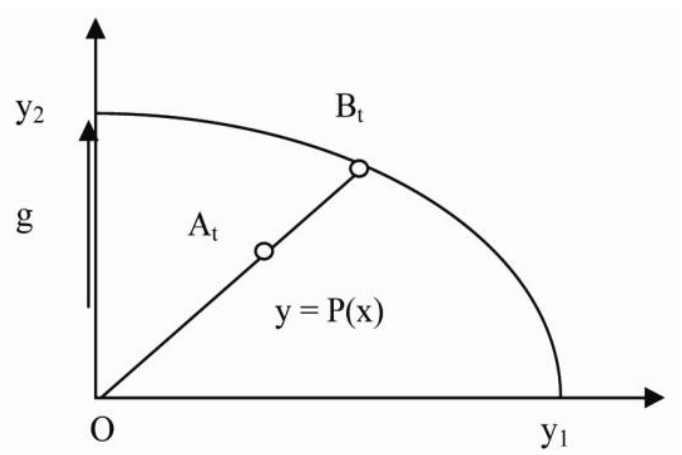

Figure 3. Output possibility set and distance functions

Figure 3 presents a production point and the production possibility frontier of the output- $\mathrm{y}_{1}$ and $\mathrm{y}_{2} . \mathrm{D}(\mathrm{y} x)$ 
indicates the output distance covered by the decision making unit from the production point $(\mathrm{O})$ to the frontier $\left(\mathrm{B}_{\mathrm{t}}\right)$. The inverse of the $\mathrm{D}(\mathrm{y} \mathrm{x})$ indicates the proportional increase in the present output $\left(\mathrm{A}_{\mathrm{t}}\right)$ to reach at the frontier $\left(\mathrm{B}_{\mathrm{t}}\right)$. By using figure-3, at $A_{t}: D^{t}\left(y^{t} x^{t}\right)=\frac{O A_{t}}{O B_{t}}<1$, and at $B_{t}: D^{t}\left(y^{t} x^{t}\right)=\frac{O B_{t}}{O B_{t}}=1$. The firm producing output at $A_{t}$ is inefficient as the point is under the frontier curve. On the other hand, the firm producing at $B_{t}$ point is efficient as the point is on the respective frontier point. To be efficient, the proportional increase of the present output level $\left(\mathrm{A}_{\mathrm{t}}\right)$ to reach at frontier lever $\left(\mathrm{B}_{\mathrm{t}}\right)$ is $\frac{O B^{t}}{O A^{t}}$.

Figure 4 shows a production point and a frontier at time $t$ and the production point and the frontier at time $(t+1)$. By using the firms' outputs production points and the frontiers, the distance functions are estimated as follows.

$D^{t}\left(y^{t}, x^{t}\right)=\frac{O A_{t}}{O B_{t}}, D^{t}\left(y^{t+1}, x^{t+1}\right)=\frac{O A_{t+1}}{O B_{t}}, D^{t+1}\left(y^{t}, x^{t}\right)=\frac{O A_{t}}{O B_{t+1}}, D^{t+1}\left(y^{t+1}, x^{t+1}\right)=\frac{O A_{t+1}}{O B_{t+1}}$. By using the four distance functions, the Malmquist productivity change index is constructed.

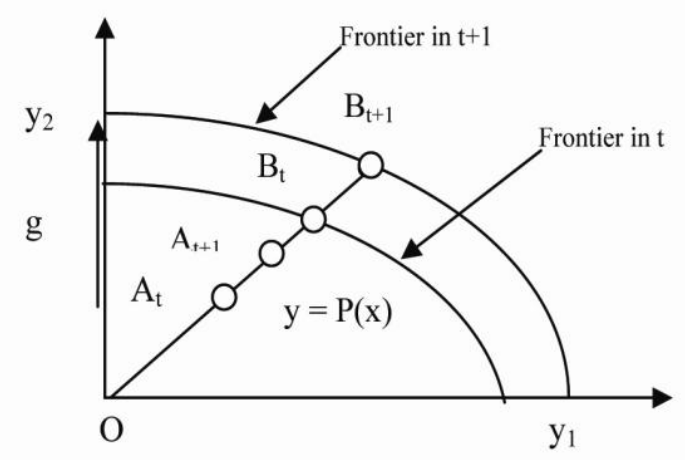

Figure 4. Distance functions and productivity indices

\subsubsection{Malmquist Index}

Malmquist (1953) proposed to compare the inputs of one period to the inputs of another period in terms of the maximum factor to reduce the inputs of one period subject to the production of the same outputs. This idea is known as Malmquist input index. Later, based on the Malmquist input index, the Malmquist output index is also developed by a researcher.

\subsubsection{Malmquist Productivity Index and Its Decomposition}

The Malmquist productivity index is used to discover the productivity difference between the two firms or one firm over the two periods of time. Malmquist productivity index is the geometric mean of the Malmquist index at the period $t$ and $t+1$. There are two Malmquist productivity indices: input-oriented Malmquist productivity index and output-oriented Malmquist productivity index. An input-oriented Malmquist productivity index is constructed by using input distance functions those describes maximum reduction in inputs by keeping outputs constant and an output-oriented Malmquist productivity index is constructed by using output distance functions those describe in maximum increase in output by keeping inputs constant. In this study, Malmquist output productivity indices are studied.

According to Caves, Christensen and Diewert (1982), the output based Malmquist productivity index between the period $t$ and $(t+1)$ is as equation (1).

$$
\operatorname{MPI}_{0}^{t}{ }^{t+1}\left(y^{t}, y^{t+1}, x^{t}, x^{t+1}\right)=\sqrt{\left[\frac{D^{t}\left(y^{t+1}, x^{t+I}\right)}{D^{t}\left(y^{t}, x^{t}\right)} \times \frac{D^{t+1}\left(y^{t+1}, x^{t+1}\right)}{D^{t+1}\left(y^{t}, x^{t}\right)}\right]}
$$

Where the notation MPI denotes the Malmquist productivity index between the two periods. The superscript (t, $\mathrm{t}+1$ ) denotes the time periods and the subscript (o) denotes the orientation. The notation D denotes the distance function. Malmquist productivity index is the geometric mean of the two Malmquist index at the period $t$ and $t+1$. The first ratio under the square root is the Malmquist output index at time $\mathrm{t}\left(M I_{o}^{t}\right)$ which measures changes in the output from period t to period $(t+1)$ by using period $t$ frontier as the benchmark and The second ratio under the square root $\left(M I_{o}^{t+1}\right)$ is the Malmquist output index at time $(t+1)$ which measures changes in the output from period $\mathrm{t}$ to period $(\mathrm{t}+1)$ by using period $(\mathrm{t}+1)$ frontier as the benchmark. In the case of output oriented Malmquist productivity index, the index is equal to zero $(\mathrm{MPI}=0)$ indicates no productivity change, the Malmquist 
productivity index is less than one (MPI $<1)$ indicates productivity decline and the Malmquist productivity index is greater than one (MPI>1) indicates productivity growth.

By rearranging the equation (1), Färe et al. (1989) proposed the Malmquist productivity index as a product of efficiency change and technical change as equation (2).

$$
\operatorname{MPI}_{0}^{t,}{ }^{t+1}\left(y^{t}, y^{t+1}, x^{t}, x^{t+1}\right)=\frac{D^{t+1}\left(y^{t+1}, x^{t+1}\right)}{D^{t}\left(y^{t}, x^{t}\right)} \sqrt{\left[\frac{D^{t}\left(y^{t}, x^{t}\right)}{D^{t+1}\left(y^{t}, x^{t}\right)} \times \frac{D^{t}\left(y^{t+1}, x^{t+1}\right)}{D^{t+1}\left(y^{t+1}, x^{t+1}\right)}\right]}
$$

In equation (2), the first term in front of the square root is the ratio of the two distance functions measures Farrell (1957) technical efficiency change (Effch) from the period t to the period $(t+1)$. The second term measures technological progress (Techch) from the period t to the period $(t+1)$. In other words, the second term, TC, measures the shift in the frontier. The term Farrell technical efficiency is greater than, equal to, or less than one (Effch $(>1,=1,<1)$ ) indicates that the firm is closer to frontier, no change, decline in productivity. The second term, Techch, is greater than, equal to, or less than one (Techch $(>1,=1,<1)$ ) indicates that the technological best practice has increased, unchanged, declined.

The Malmquist productivity index of firm-A is illustrated by using the following figure-5, considering one input one output case, assuming constant returns to scale and the equation (2). Grifell-Tatje and Lovell (1997) argued to assume constant returns to scale while estimating Malmquist productivity index as Malmquist productivity index may not capture the resulting gains or losses from scale effect while variable returns to scale is assumed. The hidden reasons are the nature of firm level and the aggregate data.

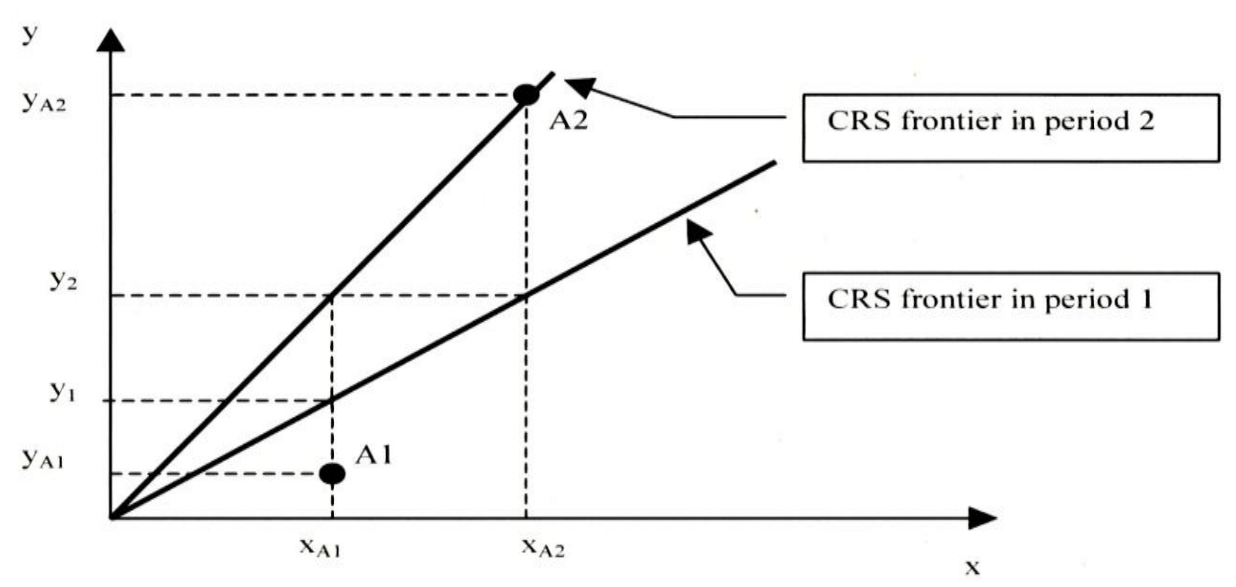

Figure 5. Malmquist productivity index

Source: Kirikal (2005), Kirikal Modified from Coelli, Rao, and Battese (1998).

In the Figure 5, the firm A produces output $\mathrm{y}$ by using input $\mathrm{x}$. The firm produces at $\mathrm{A} 1$ at time period $\mathrm{t}$ and at $\mathrm{A} 2$ at time period $(t+1)$. Firm $A$ is inefficient at time $t$, as the firm is producing at A1, under the frontier line-CRS1. However, the firm A is efficient at time $(\mathrm{t}+1)$ and producing at A2, on the frontier-CRS2. The frontier is shifted upward indicates technical advancement/progress. The technical progress includes two components: a time component and a technological component. By using the Figure 5 and the equation (2), the Malmquist productivity index is as equation (3).

$$
M_{1,2}\left(y_{A 1}, y_{A 2}, x_{A 1}, x_{A 2}\right)=\frac{y_{A 2} y_{A 2}}{y_{A 1} y_{1}}\left[\frac{y_{A 1} / y_{1}}{y_{A 1} y_{2}} x \frac{y_{A 2} y_{2}}{y_{A 2} y_{A 2}}\right]^{1 / 2}
$$

The Figure 5 shows that Malmquist productivity index of firm A is greater than 1 (MPI>1) which means growth in productivity. The sources and their magnitude to the Malmquist productivity index reflected in the efficiency change (Effch) ratio and technical progress (Techch) ratio. The efficiency change in firm A also greater than 1 $($ Effch $>1)$ which indicates increase in efficiency. The technical change is also greater than 1 (Techch > 1), upward ship, indicates technological progress.

A Malmquist Productivity index is calculated for the adjacent period by using the four distance functions: $D^{t}\left(y^{t}, x^{t}\right), D^{t}\left(y^{t+1}, x^{t+1}\right), D^{t+1}\left(y^{t+1}, x^{t+1}\right)$, and $D^{t+1}\left(y^{t}, x^{t}\right)$. There are many techniques to calculate the 
value of a distance function. The techniques available for calculating the values of the distance functions can be grouped in two broad categories: mathematical programming and econometric analysis. However, most widely used technique is the linear programming problem. Färe et al. (1994) developed DEA-friendly Malmquist productivity index. This study applies DEA-like distance functions to estimate the Malmquist productivity index.

The relationship among the Malmquist productivity change index, efficiency change, technical change, pure efficiency change, and scale efficiency change are described in the equation (4).

$$
M I=\text { Effch } * \text { Techch }=\text { Pech } * \text { Sech } * \text { Techch }
$$

Where, MI or Tfpch stands for Malmquist Productivity Index;

Effch stands for efficiency change;

Techch stands for technical change;

Pech stands for pure efficiency change;

Sech stands for scale efficiency change.

Malmquist productivity index is also known as Malmquist productivity change index, Malmquist total factor productivity change index.

\subsubsection{Constant and Variable Returns to Scale}

An important issue in productivity analysis is returns to scale properties of the production technology. The two most frequently returns to scale properties assumed in productivity analysis are constant returns to scale (Charnes, Cooper, \& Rhodes, 1978) and variable returns to scale (Banker, Charnes, \& Cooper, 1984). According to constant returns to scale, output will increase according to the increase in the input. For instance, if input is increased by 100 per cent then output will also increase by 100 per cent. On the other hand, in the case of variable returns to scale, when input increases, output increases at first and then decreases according to scale size. In figure-6, according to constant returns to scale, only the decision making unit B is efficient. However, according to variable returns to scale, all the points: A, B, C, and D, are efficient.

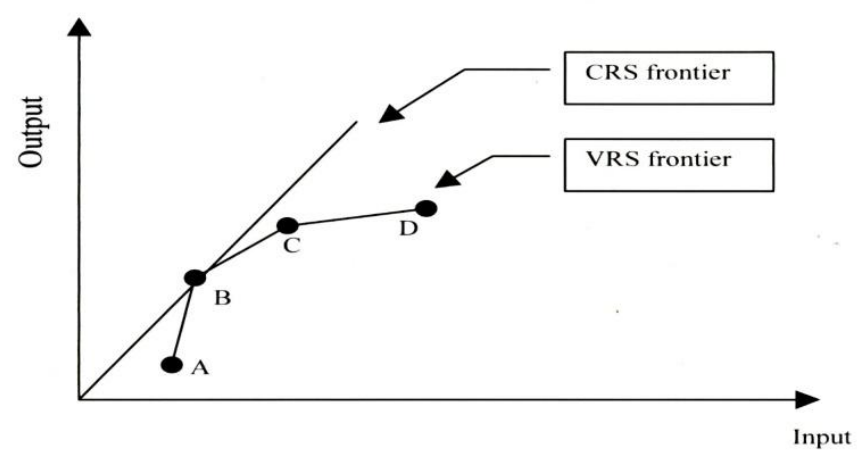

Figure 6. Constant and variable returns to scale

Source: Kirikal (2005), Kirikal Modified from Färe, Grosskopf, and Lovell (1994).

Malmquist productivity analysis can be conducted based on the assumption-production technology follows constant returns to scale or variables returns to scale. However, this study is based on the assumption that production technology follows constant returns to scale. By using one-input, one-output example, Grifell-Tatje and Lovell (1997) showed that total factor productivity is not measured correctly when it is assumed that production technology follows variable returns to scale. This happens because of nature of firm level and aggregate data. Consequently, Malmquist productivity analysis is conducted assuming production technology follows constant return to scale.

\subsubsection{Data Envelopment Analysis}

Data envelopment analysis is a linear program based program developed and proposed by Charnes, Cooper, and Rhodes (1978) to measure the efficiency of the DMUs those use the similar type of inputs and produce the similar type of outputs. The proposed model is based on the assumption of constant returns to scale and input 
orientation. The model forms a pair-wise non-linear efficient frontier and DMUs are compared with the frontier to determine the efficiency of the DMUs. However, model based on the various types of returns to scale and orientations are also developed later. Among the models developed later, Banker, Charnes, and Cooper (1984) is the most popular model. However, this study is based on the assumption that production technology follows constant returns because of practible-ness of firm-level and aggregate data.

A Malmquist productivity index for a fair of adjacent period is constructed based on a set of the four distance functions: $D^{t}\left(y^{t}, x^{t}\right), D^{t}\left(y^{t+1}, x^{t+1}\right), D^{t+1}\left(y^{t+1}, x^{t+1}\right)$, and $D^{t+1}\left(y^{t}, x^{t}\right)$. We should solve total $\mathrm{n}$ sets for $\mathrm{n}$ sample DMUS. There are many econometric and mathematical methods to estimate the values of the distance functions. However, DEA-Like linear programming problems are used to estimate the values of the distance functions in this study. The following a set of four linear programming problems-output-oriented CRS envelopment model (equation 5-8) are formulated and solved to construct the Malmquist productivity index.

(a) By comparing $y^{t}$ with the frontier at time t, i. e., determining $D^{t}\left(y^{t}, x^{t}\right)$.

$$
\left[D^{t}\left(y^{t}, x^{t}\right)\right]^{-1}=\operatorname{Max} D
$$

subject to

$$
\begin{gathered}
\sum_{j=1}^{n} \lambda_{j} x_{j}^{t} \leq x^{t} \\
\sum_{j=1}^{n} \lambda_{j} y_{j}^{t} \geq D y^{t} \\
\lambda_{j} \geq 0, j=1, \ldots \ldots n
\end{gathered}
$$

(b) By comparing $y^{t+1}$ with the frontier at time t, i. e., determining $D^{t+1}\left(y^{t+1}, x^{t+1}\right)$.

$$
\left[D^{t}\left(y^{t+1}, x^{t+1}\right)\right]^{-1}=\operatorname{Max} D
$$

subject to

$$
\begin{gathered}
\sum_{j=1}^{n} \lambda_{j} x_{j}^{t} \leq x^{t+1} \\
\sum_{j=1}^{n} \lambda_{j} y_{j}^{t} \geq D y^{t+1} \\
\lambda_{j} \geq 0, j=1, \ldots \ldots n
\end{gathered}
$$

(c) By comparing $y^{t+1}$ with the frontier at time $\mathrm{t}+1$, i. e., determining $D^{t+1}\left(y^{t+1}, x^{t+1}\right)$.

$$
\left[D^{t+1}\left(y^{t+1}, x^{t+1}\right)\right]^{-1}=\operatorname{Max} D
$$

subject to

$$
\begin{aligned}
& \sum_{j=1}^{n} \lambda_{j} x_{j}^{t+1} \leq x^{t+1} \\
& \sum_{j=1}^{n} \lambda_{j} y_{j}^{t+1} \geq D y^{t+1} \\
& \lambda_{j} \geq 0, j=1, \ldots \ldots . n
\end{aligned}
$$

(d) By comparing $y^{t}$ with the frontier at time $\mathrm{t}+1$, i. e., determining $D^{t+1}\left(y^{t+1}, x^{t+1}\right)$.

$$
\left[D^{t+1}\left(y^{t}, x^{t}\right)\right]^{-1}=\operatorname{Max} D
$$

subject to

$$
\sum_{j=1}^{n} \lambda_{j} x_{j}^{t+1} \leq x^{t}
$$




$$
\begin{gathered}
\sum_{j=1}^{n} \lambda_{j} y_{j}^{t+1} \geq D y^{t} \\
\lambda_{j} \geq 0, j=1, \ldots \ldots . n
\end{gathered}
$$

Where, $x_{j}^{t}=\left(x_{1 j}^{t}, \ldots, x_{m j}^{t}\right)$ is the inputs vector, $y_{j}^{t}=\left(y_{1 j}^{t}, \ldots ., y_{s j}^{t}\right)$ is the output vector and $\mathrm{t}=1, \ldots . . \mathrm{T}$. Where superscript denotes time period and subscript denotes DMU identity. $\lambda_{j}$ is the weight given to the DMU, $1 \leq \mathrm{D}$ $\leq \infty$ is proportional increase in the outputs keeping the inputs constant. $0 \leq 1 / \mathrm{D}(=\delta) \leq 1$ is a technical efficiency score.

\subsection{The Empirical Models}

Two models are formed to check the affect of changes in leverage on the changes in firm productivity/performance which is termed as performance model, the equation (9) and the affect of productivity/performance change index on changes in leverage which is termed as leverage model, the equation (10). In other words, the objective of the performance model is to check the affect of changes in leverage on the Malmquist productivity change index \& its components and the objective of the leverage model is to check the affect of the Malmquist productivity change index \& its components on the changes in leverage.

\subsubsection{Performance Model}

The productivity/performance model is formulated as follows:

$$
\Delta E F F_{i t}=\propto_{0}+\propto_{1} \Delta L E V_{i t-1}+\propto_{2} \Delta Z_{1 i t-1}+u_{i t}
$$

Where, $\triangle E F F$ is the productivity/its component change index, $\triangle L E V$ is the changes in leverage ratio, $\Delta Z_{1}$ is the changes in vector of the control variables, it is the observation value of firm i at time t. $u$ is the stochastic error term. The control variables are used from Uddin (2015a).

A term $\triangle L E V_{i t-1}^{2}$ is considered to include in the equation (9) on the understanding that, in the beginning stage when the firm is all equity firm or leverage is lower than optimum, if leverage increases, productivity increases. If the leverage increases, at a point, productivity reaches at the highest level, after the highest level, if the leverage is increases, the productivity is decreases simultaneously. However, the variables $\triangle L E V_{i t-1}$ and $\triangle L E V_{i t-1}^{2}$ are strongly positively correlated (0.95) and hence $\Delta L E V_{i t-1}^{2}$ not included in the equation.

\subsubsection{Leverage Model}

The leverage model is formulated as follows:

$$
\Delta L E V_{i t}=\beta_{0}+\beta_{1} \Delta E F F_{i t-1}+\beta_{2} \Delta Z_{2 i t-1}+\vartheta_{i t}
$$

Where, $\triangle L E V$ is the changes in leverage ratio, $\triangle E F F$ is the productivity/its component change index, $\Delta Z_{2}$ is the changes in the vector of the control variables, it is the observation value of firm i at time t. $\vartheta$ is the stochastic error term. The control variables are used from Uddin (2015a).

In the both model, at the time of estimation, the productivity/its component change index is replaced be the Malmquist productivity change index, technical efficiency change, technological change, scale efficiency change and pure technical change one after another. In the both model, at the time of estimation, financial leverage is replaced by leverage defined in terms of short-term debt, long-term debts and total debts one after another.

\section{The Empirical Results}

\subsection{Correlation Coefficients between the Financial Leverage Ratios (Uddin, 2015a)}

Leverage can be defined in many ways based on the objective of the study. Table 5 shows the correlation coefficients of all possible pairs. The table shows that total-debt is strongly positively related with short-term debt (0.82) and moderately positively related with long-term debt (0.54). In addition, EBIT/I and EBITD/I are perfectly correlated (1.00) but EBIT/I and EBITD/I are not correlated with other financial leverage ratios. Thus EBIT/I and EBITD/I and other financial leverage ratios represent different aspects of financing. Total liabilities ratio is not related with any other leverage ratio. Hence should not be a candidate for the financial leverage ratio. Thus based on the correlation coefficients, the leverage ratios can be summarized. 
Table 5. Correlation between the leverage ratios

\begin{tabular}{lllllllll}
\hline Debt Ratios & $S T D / T A$ & $L T D / T A$ & $T D / T A$ & $T L / T A$ & $T D /(T S+T E)$ & $L D /(L D+T E)$ & $E B I T / I$ & $E B I T D / I$ \\
\hline$S T D / T A$ & 1.00 & & & & & & & \\
$L T D / T A$ & 0.02 & 1.00 & & & & & \\
$T D / T A$ & $\mathbf{0 . 8 2}$ & $\mathbf{0 . 5 4}$ & 1.00 & & & & \\
$T L / T A$ & -0.06 & -0.07 & -0.08 & 1.00 & & & \\
$T D /(T S+T E)$ & $\mathbf{0 . 6 2}$ & $\mathbf{0 . 5 7}$ & $\mathbf{0 . 8 3}$ & -0.08 & 1.00 & & \\
$L D /(L D+T E)$ & 0.03 & $\mathbf{0 . 9 1}$ & $\mathbf{0 . 5 0}$ & -0.06 & $\mathbf{0 . 6 9}$ & 1.00 & & \\
$E B I T / I$ & -0.06 & -0.19 & -0.16 & -0.03 & -0.17 & -0.17 & 1.00 & 1.00 \\
EBITD/I & -0.06 & -0.19 & -0.15 & -0.03 & -0.16 & -0.17 & $\mathbf{1 . 0 0}$ & \\
\hline
\end{tabular}

Source: Author's Calculations.

\subsection{Affects of Changes in Leverage on Malmquist Productivity Change Index and Its Components}

Table 6 shows the effect of changes in leverage on Malmquist productivity change index and its components (equation 9 : performance model). The table is based on the 15 OLS regression results. The results of the study show that there is no significant affect of any kind of changes in leverage on the Malmquist productivity change index and its components. So, we can conclude that the changes in leverage do not affect significantly the Malmquist productivity change index \& its components.

Table 6. Affects of changes in leverage on malmquist productivity change index and its components

\begin{tabular}{lccc}
\hline MI/ its Components & $\Delta$ Leverage Ratio & P-value & Affect of $\Delta$ Leverage Ratio on MI/ its Components \\
\hline Malmquist TFP Index (Tfpch) & $\Delta$ STD/TA & $63.36 \%$ & No significant affect of changes in leverage on Tfpch \\
& $\Delta$ LTD/TA & $70.01 \%$ & \\
& $\Delta \mathrm{TD} / \mathrm{TA}$ & $78.18 \%$ & \\
\hline Technical Efficiency $\quad$ Change & $\Delta \mathrm{STD} / \mathrm{TA}$ & $34.51 \%$ & No significant affect of changes in leverage on Effch \\
& $\Delta \mathrm{LTD} / \mathrm{TA}$ & $52.80 \%$ & \\
& $\Delta \mathrm{TD} / \mathrm{TA}$ & $54.53 \%$ & \\
\hline Technological Change (Techch) & $\Delta \mathrm{STD} / \mathrm{TA}$ & $36.16 \%$ & No significant affect of changes in leverage on \\
& $\Delta \mathrm{LTD} / \mathrm{TA}$ & $90.13 \%$ & Techch \\
\hline Pure Efficiency Change (Pech) & $\Delta \mathrm{TD} / \mathrm{TA}$ & $69.46 \%$ & \\
& $\Delta \mathrm{STD} / \mathrm{TA}$ & $21.93 \%$ & No significant affect of changes in leverage on Pech \\
& $\Delta \mathrm{LTD} / \mathrm{TA}$ & $74.09 \%$ & \\
\hline Scale Efficiency Change (Sech) & $\Delta \mathrm{TD} / \mathrm{TA}$ & $31.57 \%$ & \\
& $\Delta \mathrm{STD} / \mathrm{TA}$ & $83.05 \%$ & No significant affect of changes in leverage on Sech \\
& $\Delta \mathrm{LTD} / \mathrm{TA}$ & $65.83 \%$ & \\
\hline
\end{tabular}

Source: Author's Calculations using equation (9) (Performance Model). Control variables are not reported.

\subsection{Affects of Malmquist Productivity Change Index and Its Components on Changes in Leverage}

Table 7 shows the results of the reverse causality tests- the affect of Malmquist productivity change index \& its components on the changes in leverage (equation 10: leverage model). The financial leverage is defined in terms of the short-term debts, long-term debts, and total debts. The affects of the Malmquist productivity change index $\&$ its components are checked on the changes in each financial leverage ratio. There are one OLS regression to check the affect of the Malmquist productivity change index or one of its components on one of the financial leverage ratio. Hence, the Table 7 is the summary of the 15 OLS regressions. As per the results of the analyses, the Malmquist productivity change index and its components: efficiency change, technical change, pure technical change, and scale efficiency change do not affect financial leverage defined in terms of short-term debts, long-term debts or total debts of the industry. 
Table 7. Affects of malmquist productivity change index and its components on changes in leverage

\begin{tabular}{|c|c|c|c|}
\hline $\begin{array}{c}\text { Changes in } \\
\text { Leverage Ratio }\end{array}$ & $\begin{array}{c}\mathrm{MI} / \text { its } \\
\text { Components }\end{array}$ & P-value & Affect of MI/its Components on leverage \\
\hline \multirow[t]{5}{*}{$\Delta \mathrm{STD} / \mathrm{TA}$} & TFPCH & $36.40 \%$ & Changes in MI or its components does not significantly affect changes in short-term debt \\
\hline & EFFCH & $81.40 \%$ & \\
\hline & TECHCH & $38.30 \%$ & \\
\hline & PECH & $60.40 \%$ & \\
\hline & SECH & $67.00 \%$ & \\
\hline \multirow[t]{5}{*}{$\Delta \mathrm{LTD} / \mathrm{TA}$} & TFPCH & $88.80 \%$ & Changes in MI or its components does not significantly affect changes in long-term debt \\
\hline & EFFCH & $67.80 \%$ & \\
\hline & TECHCH & $86.70 \%$ & \\
\hline & PECH & $76.90 \%$ & \\
\hline & SECH & $76.80 \%$ & \\
\hline \multirow[t]{5}{*}{$\Delta \mathrm{TD} / \mathrm{TA}$} & TFPCH & $44.40 \%$ & Changes in MI or its components does not significantly affect changes in total debt \\
\hline & EFFCH & $35.60 \%$ & \\
\hline & TECHCH & $74.10 \%$ & \\
\hline & PECH & $19.80 \%$ & \\
\hline & SECH & $76.60 \%$ & \\
\hline
\end{tabular}

Source: Author's Calculations using equation (10) (Leverage Model). Control variables are not reported.

\section{Conclusion and Future Research Directions}

This study identified the reasons of discrepancies in the previous studies about the affect of leverage on firm performance. Moreover, this study tested the affect of changes in leverage on Malmquist productivity change index \& its components and the affect of Malmquist productivity change index \& its components on the changes in leverage. The study reveals that changes in leverage do not affect Malmquist productivity change index \& its components. In addition, there is no significant reverse causality- Malmquist productivity change index \& its components do not affect the changes in leverage. Thus capital structure of the pharmaceutical sector of Bangladesh is irrelevant.

This research design should be applied on the data from other industrial sectors: : textile, food $\&$ allied products, engineering, pharmaceuticals \& chemiacals, tannery \& leather, information technology, fuel \& energy, ceramic and cement in Bangladesh in order to check the affect of changes in financial leverage on the Malmquist productivity change index $\&$ its components and the affect of Malmquist productivity change $\&$ its components on the changes in financial leverage. In addition, future researchers should conduct research on different industrial sectors from the different parts of the world so that unified understanding in the affect of the changes in leverage on the Malmquist productivity change index \& its components and the affect of the Malmquist productivity change index \& its components on the changes in leverage can be developed.

\section{Acknowledgements}

This paper is based on Chapter 4 of my YNU dissertation. My Ph.D supervisor, Professor Hiroshi Morita and Professor Akira Higashida provided invaluable guidance and advice. The scholarship from Otsuka Toshimi Scholarship Foundation, Osaka, Japan is gratefully acknowledged. Thanks to my mother-Aysha Rashid, the source of all inspirations to conduct the Ph.D thesis. I am very grateful to the co-supervisors of my dissertation: Professor Katsumasa Nishide, \& Associate Professor Yuki Itoh of Department of Business Administration, YNU and to the examiners of my dissertation: Professor Tohru Inoue, \& Associate Professor Masataka Suzuki of department of economic, YNU. The supports from staffs of Department of Business Administration-Hiromi Diamond and Takashi Kuroiwa and Students Support Division-Keiko Tsuiya and Ikegawa Manami are also significant assistances to me in conducting this research.

\section{References}

Abor, J. (2007). Debt policy and performance of SMEs: Evidence from Ghanaian and South African firms. Journal of Risk Finance, 8(4), 364-379. http://dx.doi.org/10.1108/15265940710777315

Aghion, P., \& Bolton, P. (1992). An 'incomplete contracts' approach to financial contracting. Review of Economic Studies, 59, 473-494. http://dx.doi.org/10.2307/2297860

Banker, R. D., Charnes, A., \& Cooper, W. W. (1984). Some models for estimating technical and scale 
inefficiencies in data envelopment analysis. Management Science, 30(9), 1078-1092. http://dx.doi.org/10.1287/mnsc.30.9.1078

Barclay, M., Smith, C. W., \& Morellec, E. (2006). On the debt capacity of growth options. Journal of Business, 79(1), 37-59. http://dx.doi.org/10.1086/497404

Berger, A. N., \& Bonaccorsi di Patti, E. (2006). Capital structure and firm performance: A new approach to testing agency theory and an application to banking industry. Journal of Banking \& Finance, 30, 1065-1102. http://dx.doi.org/10.1016/j.jbankfin.2005.05.015

Bevan, A. A., \& Danbolt, J. (2002). Capital structure and its determinants in the United Kingdom-A de-compositional analysis. Applied Financial Economics, 12(3), 159-170. http://dx.doi.org/10.1080/09603100110090073

Caves, D. W., Christensen, L. R., \& Diewert, W. E. (1982, March). Multilateral comparisons of output, input, and productivity using superlative index numbers. Economic Journal, Royal Economic Society, 92(365), 73-86. http://dx.doi.org/10.2307/2232257

Charnes, A., Cooper, W. W., \& Rhodes, E. (1978). Measuring the inefficiency of decision making units. European Journal of Operational Research, 2, 429-444. http://dx.doi.org/10.1016/0377-2217(78)90138-8

Chathoth, P. K., \& Olsen, M. D. (2007). The effect of environment risk, corporate strategy, and capital structure on firm performance: An empirical investigation of restaurant firms. International Journal of Hospitality Management, 26, 502-516. http://dx.doi.org/10.1016/j.ijhm.2006.03.007

Coelli, T., Rao, P., \& Battese, G. E. (1998). An introduction to efficiency and productivity analysis. Boston: Kluwer Academic Publishers. Chapter 10. http://dx.doi.org/10.1007/978-1-4615-5493-6_10

Demsetz, H. (1973). Industry structure, market rivalry and public policy. Journal of Law and Economics, 16(1), 1-9. http://dx.doi.org/10.1086/466752

Demsetz, H., \& Villalonga, B. (2001). Ownership structure and corporate performance. Journal of Corporate Finance, 7, 209-233. http://dx.doi.org/10.1016/s0929-1199(01)00020-7

Ebaid, I. E. (2009). The impact of capital structure choice on firm performance: Empirical evidence from Egypt. Journal of Risk Finance, 10(5), 477-487. http://dx.doi.org/10.1108/15265940911001385

Färe, R., Grosskopf, S., \& Lovell, C. A. K. (1994). Production frontiers. New York: Cambridge University Press. Ch. 9.

Färe, R., Grosskopf, S., Lindgren, B., \& Roos, P. (1989). Productivity developments in Swedish hospitals: A malmquist output index approach. Department of Economics Discussion Paper No 89-3, Southern Illinois University; Illinois, Carbondale. Reprinted in A. Charnes, W. W. Cooper, A. Y. Lewin, \& L. S. Seiford (Eds.), (1995). Data Envelopment Analysis: Theory, Methodology and Applications. Amsterdam: Kluwer Academic Publisher.

Färe, R., Grosskopf, S., Norris, M., \& Zhang, Z. (1994). Productivity growth, technical progress and efficiency change in industrialized countries. American Economic Review, 84(1), 66-83.

Farrell, M. J. (1957). The measurement of productive efficiency. The Journal of Royal Statistical Society, 120(A), 253-281. http://dx.doi.org/10.2307/2343100

Flannery, M. J. (1986). Asymmetric information and risky debt maturity choice. The Journal of Finance, 41, 1937. http://dx.doi.org/10.1111/j.1540-6261.1986.tb04489.x

Ghosh, A. (2007). Capital structure and firm performance. Transaction Publishers.

Gleason, K. C., Mathur, L. K., \& Mathur, I. (2000). The interrelationship between culture, capital structure and performance: Evidence from European retailers. Journal of Business Research, 50, 185-191. http://dx.doi.org/10.1016/s0148-2963(99)00031-4

Graham, J. R., \& Harvey, C. R. (2001). The theory and practice of corporate finance: Evidence from the field. Journal of Financial Economics, 60, 187-243. http://dx.doi.org/10.1016/s0304-405x(01)00044-7

Green, R. C. (1984). Investment incentives, debt, and warrants. Journal of Financial Economics, 13(1), 115-136. http://dx.doi.org/10.1016/0304-405x(84)90034-5

Grifell-Tatje, E., \& Lovell, C. A. K. (1997). The sources of productivity change in Spanish banking. European Journal of Operational Research, 98, 364-380. http://dx.doi.org/10.1016/s0377-2217(96)00353-0 
Grossman, S. J., \& Hart, O. (1982). Corporate financial structure and managerial incentives. In J. McCall (Ed.), The Economics of Information and Uncertainty. Chicago, IL: University of Chicago Press.

Harris, M., \& Raviv, A. (1991). The theory of capital structure. Journal of Finance, 46(1), 297-355. http://dx.doi.org/10.1111/j.1540-6261.1991.tb03753.x

Hu, Y., \& Izumida, S. (2008). The relationship between ownership and performance: A review of theory and evidence. International Business Research, 1(4), 72-81. http://dx.doi.org/10.5539/ibr.v1n4p72

Jensen, M. C. (1986). Agency costs of free cash flow, corporate finance, and takeovers. American Economic Review, 76(2), 323-329.

Jensen, M. C., \& Meckling, W. H. (1976). Theory of the firm: Managerial behaviour, agency costs and ownership structure. Journal of Financial Economics, 3(4), 305-360. http://dx.doi.org/10.1016/0304-405x(76)90026-x

Jermias, J. (2008). The relative influence of competitive intensity and business strategy on the relationship between capital structure and performance. The British Accounting Review, 40, 71-86. http://dx.doi.org/10.1016/j.bar.2007.11.001

Kirikal, L. (2005). Productivity, the Malmquist Index and the Empirical Study of Banks in Estonia. Ph.D Thesis, Tallinn Technical University Press. from http://digi.lib.ttu.ee/archives/2006/2006-07/1153225915.PDF

Kyerboah-Coleman, A. (2007). The impact of capital structure on the performance of micro finance institutions. Journal of Risk Finance, 8(1), 56-71. http://dx.doi.org/10.1108/15265940710721082

Lin, F. L., \& Chang, T. (2011). Does debt affect firm value in Taiwan? A panel threshold regression analysis. Applied Economics, 43, 117-128. http://dx.doi.org/10.1080/00036840802360310

Majumdar, S. K., \& Chhibber, P. (1999). Capital structure and performance: Evidence from a transition economy on an aspect of corporate governance. Public Choice, 98, 287-305.

Malmquist, S. (1953). Index Numbers and Indifference Surfaces. Trabajos de Estadistica, 4, 209-242. http://dx.doi.org/10.1007/bf03006863

Margaritis, D., \& Psillaki, M. (2010). Capital structure, equity ownership and firm performance. Journal of Banking \& Finance, 34, 621-632. http://dx.doi.org/10.1016/j.jbankfin.2009.08.023

Mlima, A. P. (1999). Dissertation: Four essays on efficiency and productivity in Swedish banking. Economiska Studier, Göteborgs Universitet.

Modigliani, F., \& Miller, M. H. (1958). The cost of capital, corporation finance, and the theory of investment. American Economic Review, 48(3), 261-297.

Modigliani, F., \& Miller, M. H. (1963). Corporate income taxes and cost of capital: A correction. American Economic Review, 53(3), 433-443.

Mostafa, M. (2007). Benchmarking top arab banks' efficiency through efficient frontier analysis. Industrial Management \& Data Systems, 107(6), 802-823. http://dx.doi.org/10.1108/02635570710758734

Myers, S. C. (1977). Determinants of corporate borrowings. Journal of Financial Economics, 5(2), 147-175. http://dx.doi.org/10.1016/0304-405x(77)90015-0

Ofori-Dankwa, J., \& Julian, S. D. (2013). Dynamism, capital structure and performance in a sub-Saharan economy: Extending the institutional difference hypothesis. Organization Science, 24(5), 1422-1438. http://dx.doi.org/10.1287/orsc.1120.0789

Phillips, P. A., \& Sipahioglu, M. A. (2004). Performance implications of capital structure: Evidence from quoted UK organizations with hotel interests. The Output Industries Journal, 24(5), 31-51. http://dx.doi.org/10.1080/0264206042000276829

Rajan, R. G., \& Zingales. (1995). What do we know about capital structure? Some evidence from international data. The Journal of Finance, 50, 1421-1460. http://dx.doi.org/10.1111/j.1540-6261.1995.tb05184.x

Ross, Westerfield, \& Jaffe. (2012). Corporate finance (10th ed.). McGraw-Hill.

Shephard, R. W. (1970). Theory of cost and production functions. Princeton: Princeton University Press.

Simerly, R. L., \& Li, M. (2000). Environmental dynamism, capital structure, and performance: A theoretical integration and an empirical test. Strategic Management Journal, 21, 31-49. 
http://dx.doi.org/10.1002/(sici)1097-0266(200001)21:1<31::aid-smj76>3.3.co;2-k

Singh, M., \& Faircloth, S. (2005). The impact of corporate debt on long-term investment and firm performance. Applied Economics, 37(8), 875-883. http://dx.doi.org/10.1080/00036840500076762

Smith, J. R., \& Warner, J. B. (1979, March). Bankruptcy, secured debt, and optimal capital. structure: Comments. Journal of Finance, 34, 247-252. http://dx.doi.org/10.1111/j.1540-6261.1979.tb02085.x

Stulz, R. M. (1990). Managerial discretion and optimal financing policies. Journal of Financial Economics, 26, 3-27. http://dx.doi.org/10.1016/0304-405x(90)90011-n

Titman, S., \& Wessels, R. (1988). The determinants of capital structure choice. The Journal of Finance, 43(1), 1-19. http://dx.doi.org/10.1111/j.1540-6261.1988.tb02585.x

Uddin, N. (2015a). Determinants of corporate capital structure: A theoretical integration and some empirical evidences. International Journal of Economics and Finance, 7(7), 254-277. http://dx.doi.org/10.5539/ijef.v7n7p254

Uddin, N. (2015b). Productivity growth, efficiency change, \& technical progress of a corporate sector in Bangladesh: A malmquist output productivity index approach. International Journal of Economics and Finance, 7(8), 240-255. http://dx.doi.org/10.5539/ijef.v7n8p240

Van Horne, J. C. (2002). Financial management policy (12th ed.). Delhi Pearson Education Asia.

Welch, I. (2004). Capital structure and stock returns. Journal of Political Economy, 112, 106-131. http://dx.doi.org/10.1086/379933

Lin, W., Liu, C., \& Chu, C. (2005). Performance efficiency evaluation of the Taiwan's shipping industry: An application of data envelopment analysis. Proceedings of the Eastern Asia Society for Transportation Studies, 5, 467-476. http://dx.doi.org/10.1108/15265940710721082

Weston, J. F., \& Brigham, E. F. (1984). Management finance (p. 555). Illinois: The Dryden Press.

\section{Copyrights}

Copyright for this article is retained by the author(s), with first publication rights granted to the journal.

This is an open-access article distributed under the terms and conditions of the Creative Commons Attribution license (http://creativecommons.org/licenses/by/3.0/). 